\title{
Orhan Pamuk Romanları Temelinde Metinsel-Aşkınlık İlişkileri Terminolojisine Bir Katkı: Özgönderge-metin, Özgöndergeleştirim, Özalıntı, İçalıntı Kavramları*
}

\author{
Gizem KUNDURACI* \\ Muharrem DAYANÇ**
}

\section{$\ddot{\mathbf{O} z}$}

Metinsel-aşkınlık ilişkileri kuramı, belirli ölçüde Ferdinand de Saussure tarafından tasarlanarak yirminci yüzyıl dil biliminin temelini teşkil eden Yapısalcılık kuramına, önemli ölçüde Mihail Bahtin tarafından temsil edilen biçimci anlayışa dayanmaktadır. Saussure'ün dil araştırmalarında ortaya koyduğu eşsüremli yaklaşım, Rus Biçimcileri tarafından metin incelemelerinde bir dayanak hâlini almıştır. Yazınsal okumalar üzerine dil bilimine dayalı bakış açıları geliştirmiş olan kuramcılar, 1915-1930 yılları arasında Moskova Dilbilim Çevresi ile Şiirsel Dil Araştırmaları Derneği etrafında bir araya gelmişlerdir. Aralarından Bahtin'in Dostoyevski romanları üzerine gerçekleştirdiği inceleme, çokseslilik, söyleşim ve söyleşimcilik kavramlarının metin okumada bir dayanak hâlini almasıyla ilgili kavramların kuramlaşması ve Julia Kristeva ile Metinlerarasılık kuramının dayanaklarını oluşturması sağlanmıştır. Gerard Genette ise, Metinsel-aşkınlık kavramını tasarlayarak "metinlerarası" olgusunu metinsel-aşkınlık biçimleri arasında değerlendirmiştir. Belirli bir metni metinsel-aşkın nitelikli okuma tecrübesiyle alımlayan okur, ana-metindeki gönderimi doğrudan doğruya gerçekleştirilmiş olmayan her bir metni, kendi ekinsel ve yazınsal tecrübesine bağlı olarak tespit edebilmektedir. Kimi zaman, ana-metnin üreticisinin herhangi bir biçimde maruz kalmadığı bu türden örüntüsel metinler, yalnızca okurun tek bir eşsüremli okuma tecrübesinde ortaya çıkabilmektedir. Belirli bir ana-metin, tek bir okur tarafından farklı süreçlerde gerçekleştirilen metinsel-aşkın nitelikli okuma tecrübeleri neticesinde, farklı metinsel-aşkın görünümler kazanabilmektedir. Metinlerarası ya da metinsel-aşkın çerçeveli okuma, önemli ölçüde okurluk tecrübesine bağlı olarak dönüşüm hâlindedir. Nitekim ana-metnin üreticisi olan metinlerarası yazar da kendi okurluk tecrübeleri neticesinde söz konusu metni üretmektedir. Orhan Pamuk romanları, metinsel-aşkınlık ilişkileri bakımından estetik bir çerçeveye sahip olmakla birlikte metin-ötesi görünümleri bakımından kuramsal bir düzlem oluşturmaktadır. Pamuk’a ait romanlar metinselaşkınlık çerçeveleriyle ele alındığında söz konusu metin ötesi ilişkilerin belirli bir metinlerarası anlam oluşturmakla birlikte roman yazarına ait bir okuma haritasıyla roman kuramına işaret ettiği anlaşılmaktadır. Bu ilişkilerde tespit edilen bazı gönderim biçimleri, daha önce adlandırılmasına rastlanmamış bazı teknikler olarak dikkat çekmektedir. Bu incelemede özgöndergeleştirim, özalıntı ve içalıntı olarak adlandırılan söz konusu tekniklerin metin-ötesi ilgiler bakımından işlevlerinin ortaya konması amaçlanmaktadır.

Anahtar Kelimeler: Metinsel-Aşkınlık, Metinlerarasılık, Özgönderge-metin, Özgöndergeleştirim, Özalıntı, İçalıntı.

\footnotetext{
* Bu inceleme, Prof. Dr. Muharrem DAYANÇ danışmanlığında yürütülüp 2019 yılında tamamlanan "Metnin Ötesinde, Metinler Arasında Dolaşım: Orhan Pamuk'un Romanlarında Metinsel-Aşkınlık Görünümleri” başlıklı doktora tez çalışmasından hareketle meydana getirilmiştir. [Çalışmanın künyesi: Kunduracı, Gizem (2019) "Metnin Ötesinde, Metinler Arasında Dolaşım: Orhan Pamuk’un Romanlarında Metinsel-Aşkınlık Görünümleri”, Eskişehir: Eskişehir Osmangazi Üniversitesi Sosyal Bilimler Enstitüsü: (Yayınlan- mamış Doktora Tezi).]

**Dr., Eskişehir Osmangazi Üniversitesi Fen Edebiyat Fakültesi, Karşılaştırmalı Edebiyat Bölümü, Eskişehir, Türkiye. Elmek: gkunduraci@ogu.edu.tr

https://orcid.org/0000-0001-8448-9322.

***Prof. Dr., İstanbul Medeniyet Üniversitesi, Edebiyat Fakültesi, Türk Dili ve Edebiyatı Bölümü, İstanbul, Türkiye.

Elmek: mdayancm@gmail.com

https://orcid.org/0000-0002-0120-3374.
} 


\title{
A Contribution to the Terminology of Transtextuality Relations Based on Orhan Pamuk's Novels: Selfreferential-text, Self-referation, Self-citation, Internal-citation Concepts
}

\begin{abstract}
The transtextuality theory is based, to a certain extent, on the theory of Structuralism, which was conceived by Ferdinand de Saussure and formed the basis of twentieth-century linguistics, the formalist understanding represented significantly by Mikhail Bakhtin. The synchronic approach that Saussure put forward in language research has become a basis for text studies by Russian Formalists. Theorists who developed linguistic perspectives on literary readings came together around the "Moscow Linguistic Circle" and the "Society for the Study of Poetic Language" (Yücel 2008: 121) between 1915-1930. Among them, Bakhtin's analysis of Dostoyevsky's novels has been provided to theorize the concepts related to the concepts of polyphony, dialogy and dialogism becoming a basis in reading texts, and to form the basis of the intertextuality theory with Julia Kristeva. Gerard Genette, on the other hand, designed the concept of transtextuality and evaluated the "intertextuality" phenomenon among transtextual forms. The reader, who receives a certain text with a transtextual quality of reading experience, can identify each text in the base-text, which is not directly transmitted, depending on his own cultural and literary experience. In some cases, such patterned texts, to which the producer of the base-text is not exposed in any way, can only emerge in a single concurrent reading experience of the reader. A particular base-text can acquire different transtextual appearances as a result of transtextual reading experiences performed by a solitary reader in different processes. Intertextual or transtextual framed reading is in a state of transformation, depending significantly on the experience of reading. As a matter of fact, the intertextual writer, who is the producer of the base-text, produces the text in question as a result of his own reading experiences. Although Orhan Pamuk's novels have an aesthetic frame in terms of transtextual relations, they constitute a theoretical platform in terms of their transtextual appearances. When Pamuk's novels are handled with transtextuality case, it is understood that these transtextual relations constitute a certain intertextual meaning and point to the novel theory with a reading plan belonging to the novelist. Some forms of reference found in these relationships attract attention as some techniques that have not been named before. With this examination, it is aimed to reveal the functions of these techniques, which are called self-indication, self-quote and introspection, in terms of transtextual concerns.
\end{abstract}

Keywords: Transtextuality, Intertextuality, Selfreferential-text, Selfreferation, Self-citation, Internalcitation. 


\section{Extended Summary}

The theory of linguistics based on the Structuralist approach developed by Ferdinand de Saussure constitutes one of the starting points of the so-called Russian Formalists, who put their linguistic perspectives on the field of literature based on the literary phenomenon. Russian Formalists, including researchers such as Vladimir Propp and Mikhail Bakhtin, apply linguistic perspectives to the text in question, based on the determination of the literacy of a text whose specificity is determined, independent of markers such as society, history, and biography. Formalists discussed derivative relations such as parody and pastiche, which constitute the frame of the transtextuality theory in terms of method. Especially, Propp, which deals with Russian folk tales with the archetypal method of analysis, significantly represents the effectiveness of this community in the field of literature (Kundurac1 2019: 4). The adaptation of linguistics to the field of literature gained a new perspective when Bakhtin, among the Formalists, incorporated the concepts of polyphony and conversational dialogy into the theoretical plane through the texts of Dostoyevsky and Rabelais.

In the field of semiotics, Roland Barthes ${ }^{1}$ evaluates the text as a texture composed of quotations from numerous cultural centers (Barthes 1977: 146). From this point of view, it is understood that Barthes evaluates the intertextual phenomenon, which enables the production of a new text in the context of synchrony, among the basic criteria of literacy and evaluates the reader's effectiveness at the forefront.

While Michael Rifaterre defines the intertextual phenomenon according to the relationship between the reader and the text, it gives a function to the reader and the reading activity (Aktulum 1999: 60). By finding the act of reading effective in the emergence of transtextual forms that occur through the "traces" in a certain base-text, it emphasizes the synchronicity. Thus, both approaches involve the transfer of the concept of synchronism, which Saussure directed to the field of twentieth century linguistics, to the text plane.

Julia Kristeva ${ }^{2}$ revealed the concept of intertextuality by conceptualizing the

1 Roland Barthes, "The Death of Author", Image, Music, Text (Ed.\&Trans.: Stephen Heath), Fontana Press, London, 1977. 2 Julia Kristeva, Desire in Language: A Semiotic Approach to Literature and Art (Ed.: Leon S. Roidiez; Trans.: Thomas Gora, Alice Jardine, Leon S. Roidiez) Columbia University Press, New York, 1980. 
concepts of dialogy and polyphony, which Bakhtin put forward in a carnivalized text, as features determined in a particular base-text. Accordingly, a particular text is in conversation with texts other than itself and in this context it is polyphonic. Like the theorists before him, Laurent Jenny, who first evaluated the intertextuality and the quality of intertextuality or transtextuality among the literary criteria found in a certain text, by making the placement of different texts in a text into the base-texts and classifying the transtextual forms (Aktulum 1999: 41), like Kristeva, is another starting point for Gérard Genette.

Genette $^{3}$, who systematizes the transtextuality theory by treating the secondorder literary texts within the frame of palimpsest narratives, expresses the complex reading and text production style, which was expressed with the concept of intertextuality before him, with the concept of transtextuality in a way that expresses beyond a text.

Using techniques such as citation, reference, allusion; referent, epigraph, palimpsest, etc. each "external" element identified in the base-texts as a result of the processes of rewriting such as reduction, extension, and conversion into mise en abyme in forms constitutes the transtextuality terminology.

The quotation method, which is widely detected in transtextual relations, is a kind of referential method that can be detected during the act of reading, since it is mostly directly mentioned in the base-text. Here, the referent-text is entered into the base-text by means of quotation, epigraph or metaphor, the determination of which is relatively dependent on cultural sources. Such "texts" that are understood to be included in the main text by directly mentioning or quoting are considered as referenttext. Apart from these, there are some forms of quotation or recall made from texts belonging to the author of the base-text. These, unlike the basic referent-text, form a framework for the novel theory of the producer of the text, as well as establishing transtextual relations with semantic-thematic frames. This tendency makes each individual text a great river-narrative (based on the concept of the roman-fleuve, saga novel or river-novel), thanks to the quotations and reminiscences among themselves, although this tendency is mostly a playful novel constructing technique, especially in internal-citation applications. Thus, reference to the concepts of self-citation, internalcitation, selfreferential-text in determining and interpreting transtextual relations can be considered as a contribution to the theoretical terminology.

3 Gérard Genette, Palimpsests: Literature in the Second Degree (Trans.: Channa Newman, Claude Doubinsky), University of Nebraska Press, USA, 1997. 
This type of quotation and reminiscence (self-reference and hence selfcitation), which is a kind of reference text through the placement of "other", "different" texts or sentences belonging to the author of the main text on the basis of Orhan Pamuk's novels, is often used as a whole. When each text is put together, it forms a large base-text, in other words a roman-fleuve (or saga novel). Likewise, with the internal-citation method, a certain part of the base-text is taken and repeated elsewhere and a theme, image or phrase is emphasized in the base-text.

All kinds of quotations identified as self-referentials in a particular base-text are interpreted as "essence" citations in terms of containing the words of the text producer. Thus, self-citation (the text producer repeating a word in the main text or quoting from another word of his own) and as a result of this, the self-citation method emerges as a transtextual technique, based on the act of self-citation.

Based on the transtextual forms identified in Orhan Pamuk's novels, the techniques that form the forms of interest and relation beyond a text called "self-referation,", "self-citation", "internal-citation" are brought to the attention to be remembered in the intertextual readings. It is doubtless that the theory of transtextual relations, which is considered quite new in terms of the formation of Turkish terminology, will reach a kind of unity in style and terminology with the increase of similar studies. 



\section{Giriş}

Metinsel-aşkınlık ilişkileri kuramı, metne dönük bir oluşturma kuramı olmakla birlikte, metinsel-aşkın nitelikli bir okuma yoluyla bir metnin anlamının ortaya çıkarılması, metni alımlayan okurun ekinsel birikimine ve okurluk tecrübesine bağlı bulunmaktadır. Belirli bir ana-metnin üreticisi konumunda bulunan ve aynı zamanda bir "metinlerarası okur" olduğu kabul edilen yazarın kuramsal bir bakış açısıyla ve bilinçli bir biçimde başvurabildiği metinsel-aşkın nitelikli metin üretimi, belirli bir ana-metne nüfuz etmiş "başka" metinlerin çağrışımsal biçimde göndergeleşmesi, kimi zaman yenidenyazılması yoluyla da gerçekleşebilmektedir. Aynı zamanda metinsel-aşkınlık ya da bir metnin kendisinden daha fazlasını içerdiği ve ifade ettiği metin-ötesi, belirli bir ana-metnin anlamını üretmede temel bir dayanak olabileceği gibi, söz konusu ana-metnin estetik çerçevesini oluşturan bir süs/bezek unsuru olarak da ortaya çıkabilmektedir.

Türkçe terminolojide bulunan alıntı ve gönderge yöntemleriyle gönderge-metin kavramı, Genette'in terminolojisinden aktarım sonucu dolaşıma getirilmiş kavramlar olarak dikkat çekmektedir. Nitekim, bu konuda Aktulum'un sunmuş olduğu ${ }^{4}$ adbilimsel çeviriler kavramların işlevsel etki alanlarıyla büyük ölçüde örtüşmektedir. Bununla birlikte, ele alınan metinler ve bu metinlerin ortaya çıkarılmış metinsel-aşkın bağıntıları niceliksel olarak genişledikçe, tespit edilen yeni kavramların ve işlevlerin adlandırılması ihtiyacı ortaya çıkmaktadır.

Orhan Pamuk romanlarının metinsel-aşkın ve estetiksel-aşkın çerçevelerinin ortaya çıkarılması amacıyla metin-ötesinin araştırmaya konu edildiği incelemede ${ }^{5}$, literatürde yer almamış bazı işlevler tespit edilmiş ve kavramlaştırılması önerilmiştir. Buna göre, alıntılama ve göndergeleştirim işlemleri, ana-metnin yazarının kendisine ait metinler arasında gerçekleştirildiğinde, metinsel-aşkın bağlamlı anlam üretimi bakımından bir işlevsellik dikkati çekmiştir. Bu nedenle, nicelik bakımından geniş kapsamlı biçimde izlenebilen eğilim, metin üreticisinin kendi eserleri içerisinden ve kendi izleksel çerçevesinden gerçekleştirilmiş olması sebebiyle öz-alıntı kavramıyla

4 Bk.: Aktulum, Kubilây (1999), Metinlerarası İlişkiler, Ankara: Öteki Yayınları.; Aktulum, Kubilây (2011), Metinlerarasllık/Göstergelerarasılık, Ankara: Kanguru Yayınları.

5 [Bk.:Kunduracı, Gizem (2019), "Metnin Ötesinde, Metinler Arasında Dolaşım: Orhan Pamuk’un Romanlarında Metinsel-Aşkınlık Görünümleri”, Eskişehir: Eskişehir Osmangazi Üniversitesi Sosyal Bilimler Enstitüsü: (Yayınlanmamış Doktora Tezi)]. 
izah edilmektedir. Bir ana-metinde yer alan söz konusu ana-metnin yazarına ait alıntı ve anımsamalar, birer gönderge-metni oluşturduğunda, bu tür gönderge-metinler özgönderge metin olarak adlandırılmaktadır.

Belirli bir ana-metinde kimi izleksel hususiyetlerin ya da üslup özelliklerinin vurgulanmak istediği kullanımlar da tespit edilebilmektedir. Bazı yinelemeler, alıntılar ya da anımsamalar yoluyla meydana getirilen bu öz-alıntılama biçimi ise, ele alınan ana-metnin içerisinde gerçekleştirilmesi sebebiyle iç-alıntı olarak adlandırılmaktadır. Böylece, mevcut terminolojiye ilave olarak dikkate sunulmuş Türkçe terim önerileriyle metinsel-aşkınlık biçimlerinin göstergebilimsel işlevlerinin daha açık biçimde tespit ve izah edilebilmesinin sağlanması amaçlanmaktadır.

\section{Ana Hatlarıyla Metinsel-Aşkınlık Kuramı Terminolojisi}

Yirminci yüzyıl dil bilimi sahasında Ferdinand de Saussure'e ait yapısalcı yaklaşımla birlikte ortaya çıkan modern dil bilimi, dil araştırmalarının yanında, dil olgusundan hareketle belirli bir metnin yazınsallığının tespitiyle dilsel birer ürün olarak edebî malzeme temelinde yapısalcı incelemeyi öngören farklı disiplinlerin istikametlerinde de tesirde bulunur. Dil bilimine dayalı biçimde gelecekte ortaya çıkacak bir araştırma alanı olarak genel bir göstergeler biliminden ya da göstergebilim disiplininden haber veren Saussure ${ }^{6}$, edebiyat dışında insana dair her türlü anlatımın dil biliminden hareketle tahlilini bu tasavvurla öngörür.

Saussure tarafından geliştirilen Yapısalcı dil bilimi kuramı, yazınsallık olgusundan hareketle dil bilimsel bakış açılarını edebiyat sahasına uygulamaya koyulan, "Moskova Dilbilim Çevresi" ile "Şiirsel Dil Araştırmaları Derneği " etrafında (Yücel 2008: 121) bir araya gelmiş olan ve Rus Biçimcileri olarak adlandırılan teorisyenlerin çıkış noktalarından birini teşkil eder. Aralarında Vladimir Propp, Mihail Bahtin gibi araştırmacıların yer aldığı Rus Biçimcileri, toplum, tarih, biyografi gibi işaretleyicilerden bağımsız ve özgüllüğü saptanmış bir metnin yazınsallığının tespitinden hareketle söz konusu metne dil bilimsel bakış açılarını uygular. Biçimciler, edebiyat metnini metinsel-aşkınlık kuramının yöntem bakımından çerçevesini teşkil eden parodi (yansılama), pastiş (öykünme) gibi türev ilişkilerini ele almışlardır. Bilhassa Rus halk masallarını arketipik inceleme metoduyla ele alan Propp ${ }^{7}$, bu topluluğun edebiyat sahasındaki etkinliğini önemli ölçüde temsil etmektedir. Dil biliminin edebiyat sahasına intibak ettirilmesi, Biçimciler arasından Bahtin'in, çokseslilik (polyphony) ve söyle- 
şim (dialogy) kavramlarını ${ }^{8}$ Dostoyevski ve Rabelais metinleri üzerinden kuramsal düzleme dâhil etmesiyle ise dil bilimine dayalı biçimci yaklaşımın yazınsal düzlemde yeni bir perspektif kazandığı bilinmektedir.

Yapısalcı dil biliminden hareketle metinlerarasılık (intertextuality) kavramını tasarlayan Julia Kristeva, Rus Biçimcileri arasında değerlendirilen Mihail Bahtin'e ait söyleşim ve çokseslilik kavramlarından yola çıkar. Bahtin, söz konusu kavramları Dostoyevski romanlarını ele aldığı Türkçe olarak "Dostoyevski Poetikasının Sorunlarl" adıla basılan incelemesiyle ve karnaval kültürünün bir yansıması olarak ele aldığı Rabelais romanlarına dair değerlendirmelerinden mürekkep "Rabelais ve Dünyası" "10 incelemesinde öne sürer. Ona göre her bir karakterin özgül ve müstakil biçimde ifade imkânı bulmakta olan Dostoyevski eserleri, bu anlamda çoksesli birer yapıdadır. Yazarın sesinin de tespit edilebildiği bu metinlerde yazar, özgül bir ses olarak hiçbir karakterle özdeş bulunmadan yer alır. Rabelais ise orta çağ karnaval kültürünün bir uzantısı olarak romanlarında farklı türden anlatımların bir arada homojen biçimde bulunmasını sağlar. Böylece, karnavallaşmış ${ }^{11}$, "melez" bir anlatım sunar. Halk anlatılarından kutsal ifadelere, yüksek edebi biçimlerden komikleşmiş edebî türlere çok üsluplu ana-metinde her bir tür, "söyleşim" hâlinde bulunur. Söyleşim ve çokseslilik, belirli bir ana-metinde farklı metinlerin, farklı sanat biçimlerinin ve nihayet farklı "söz"12lerin bir arada bulunduğu metinsel-aşkın yapılı anlatılar için de belirli bir karekteristiği temsil etmektedir. Her biri bir üslup, bir bakıma birer "söz" olan "metin”ler ya da söz zinciri parçaları, belirli bir metnin kendisi

8 Bk.: Bakhtin, M. Mikhail (1981), The Dialogic Imagination: Four Essays (Ed.: Michael Holquist; Trans.: Caryl EmersonMichael Holquist), Texas: University of Texas Press, Austin.

9 Bahtin, M. Mihail (2015), Dostoyevski Poetikasının Sorunları (Çev.: Cem Soydemir), 2. b., İstanbul: Metis Yayınları, (1. Bask1: 2004).

10 Bahtin, M. Mihail (2005), Rabelais ve Dünyası (Çev. Çiçek Öztek), İstanbul: Ayrıntı Yayınları.

11 Karnaval kültürünün edebiyat sahasına tezahürü ve bu neticede bir kavram olarak tasarlanan karnaval anlatı ya da karnavallaşmış anlatı türü için bk.: Bahtin, M. Mihail (2014), Karnavaldan Romana: Edebiyat Teorisinden Dil Felsefesine Seçme Yazılar (Çev. Cem Soydemir, Der. Sibel Irzık), 2. b., İstanbul: Ayrıntı Yayınları.

12 “Söz" kavramı için, “Açıklamalı Dilbilim Terimleri Sözlüğü”nde, Saussure’ün dil ile söz arasında gerçekleştirdiği ayrıma değinilerek toplumsal nitelikli dilden ayrı biçimde, konușan bireyin kişisel düşüncesini anlatmak üzere, dil dizgesini kullanmasını sağlayan türlü vasıtaları kapsadığı ifade edilir. Kavram, "[d]ilyetisinin kişisel bir istenç ve anlak eylemiyle özdeşleşen bireysel yanı" (Vardar vd. 2007: 180) olarak tanımlanır.

Yücel (2008: 28), dilin tutarlı bir yanına ulaşmayı çalıştığını belirttiği Saussure’ün, dilyetisinin bireysel gerçekleşimi olan söz ile toplumsal veçhesini oluşturan dil arasında gerçekleştirdiği karşılaştırmadan, yapısalcı yaklaşımın dayanaklarını oluşturan başlıca karşıtlıklardan biri olarak söz eder.

Barthes ise, söz olgusunu, "bireysel bir seçme ve gerçekleştirme edimi" (Barthes 2016: 31) ibaresiyle tanımlar. Göstergebilim kuramını oluşturmada giyim kuşam benzetmesinden yola çıkan Barthes, (2016: 39-42), "giyim" olarak ele aldığı dil olgusuyla "giyinme" olarak ele aldığı söz olgusunu genel ve varsayımsal biçimde de olsa önceden belirlemenin göstergebilimsel açıdan artık olanaklı olmadığını belirtir. Nitekim, görüntü dili ya da müzik dili gibi, hakkında kapsamlı bilgiye sahip olunmayan dilsel dizgelerden söz eder.

Söz kavramının dilin bireysel yanı olarak ele alınışından hareketle, ana-metnin üreticisi olan yazarın belirli bir "metin”de kendi "söz"ünü gerçekleştirdiği düşünülebilir. Çoksesli ve söyleşimsel, kuramsal ifadeyle, metinsel-aşkın nitelikli metinlerde, birbirinden farklı, müstakil sözlerin bir araya gelerek birbirleriyle doğal bir iletişim kurduklarını, bu beraberlikle homojen yapıyı teşkil eden metnin bütününü oluşturduklarını ifade etmek mümkündür. 
dışındaki "başka" metinlerle örülmesini sağlamaktadır. Bu mozaik yapı, aynı zamanda hem metin-ötesi hem metnin kendisidir.

Göstergebilim alanında Roland Barthes ${ }^{13}$ ise, metni sayısız kültür merkezinden alınan alıntılardan oluşmuş bir doku olarak (Barthes 1977: 146) değerlendirir. Buradan hareketle, Barthes'ın eşsüremlilik bağlamında yeni bir metin üretimini sağlayan metinlerarası olgusunu yazınsallığın temel ölçütleri arasında değerlendirdiği ve okurun etkinliğini ön sıralarda değerlendirdiği anlaşılır. Micheal Rifaterre, metinlerarası olgusunu okur ile metin arasındaki ilişkiye göre tanımlarken, okura ve okuma etkinliğine bir işlev yükler (Aktulum 1999: 60). Belirli bir ana-metindeki “iz”ler yoluyla meydana gelen metinsel-aşkınlık biçimlerinin ortaya çıkmasında okuma edimini etkin bulmakla ise eşsüremli niteliği vurgulamış olur. Böylece, her iki yaklaşım sayesinde, Saussure tarafından yirminci yüzyıl dil bilimi sahasına yöneltilmiş olan eşsüremlilik kavramının metin düzlemine taşınması ve yazınsal çerçevede kuramlaşması söz konusu olur. Julia Kristeva ${ }^{14}$, Bahtin'in ana hatlarıyla karnavallaşmış bir metinde tespit ederek ortaya koyduğu söyleşim ve çokseslilik kavramlarını belirli bir ana-metinde saptanan özellikler biçiminde kavramlaştırarak metinlerarasılık (intertextuality) kavramını ortaya koyar. Buna göre, belirli bir metin, kendisinden başka metinlerle söyleşim hâlindedir ve bu bağlamda çokseslidir. Kendisinden önceki kuramcılar gibi, metinlerarası olgusuyla metinlerarasılık ya da metinsel-aşkınlık niteliğini belirli bir metinde bulunan yazınsallık ölçütleri arasında başta değerlendiren Laurent Jenny ise, bir metinde bulunan farklı metinlerin ana-metinlere yerleşme biçimlerini ulamlaştırması ve metinsel-aşkınlık biçimlerini tasnif etmesiyle (Aktulum 1999: 41), Kristeva gibi, Genette için diğer bir başlangıç noktasını oluşturur.

İkinci dereceden edebiyat metinlerini palimpsest anlatılar çerçevesinde ele alarak metinsel-aşkınlık kuramını önemli ölçüde sistematize eden Gérard Genette ${ }^{15}$ ise, kendisinden önce metinlerarası ya da metinlerarasılık (intertextuality) kavramıyla ifade edilen kompleks okuma ve metin üretme biçimini, bir metnin ötesini de ifade edecek biçimde metinsel-aşkınlık (transtextuality) kavramıyla ifade eder. Genette tarafından tasavvur edilen metinsel-aşkınlık (transtextulaity) ${ }^{16}$ olgusu, kendisi ve kendisi dışındaki farklı göndergelerden, palimpsestlerden oluşan, zaman zaman kendisine

13 Barthes, Roland (1977), "The Death of Author", Image, Music, Text (Ed.\&Trans.: Stephen Heath), London: Fontana Press.

14 Kristeva, Julia (1980) Desire in Language: A Semiotic Approach to Literature and Art (Ed.: Leon S. Roidiez; Trans.: Thomas Gora, Alice Jardine, Leon S. Roidiez), New York: Columbia University Press.

15 Genette, Gérard (1997), Palimpsests: Literature in the Second Degree (Trans.: Channa Newman, Claude Doubinsky), USA: University of Nebraska Press, USA.

16 Bk.: Genette, Gérard (1997a), Palimpsests: Literature in the Second Degree (Trans.: Channa Newman, Claude Doubinsky), USA: University of Nebraska Press. 
gönderimde bulunan, oyunsu ipuçları taşıyan çoklu yapıdaki bir metnin yorumlanmasında metinsel-aşkınlık durumlarının karşılanması bakımından daha kapsayıcı bir ifade olarak ortaya çıkar. Buna göre metin-ötesi örüntülere sahip belirli bir metin, aynı zamanda ele alınan temel metin, ana-metin (hypertext) olarak kabul edilmekte, bu metnin kendisi dışındaki metinlerle anlatım biçimleri, üsluplar, kuram ve yöntemlerle ilişkileri sırasıyla metinlerarası, ana-metinsellik, üst-metinsellik, yorumsal üstmetinsellik gibi söyleşim biçimleriyle ortaya çıkmakta ve anlaşılmaktadır. Ana-metinde yer alan "başka" unsurlar, alıntı, gönderge, palimpsest, alt-metin gibi biçimlerde bulunmakta; bunlar da anlamsal ya da biçemsel kimi dönüştürüm işlemleri sonucunda ana-metnin anlamının üretilmesinde etkili bulunmaktadır.

Metne dayalı ve kısmî olarak okura bağlı biçimde işleyen metinsel-aşkınlık, bir okuma biçiminin yanı sıra kuramsal bir üretme biçimidir. Çoksesli, söyleşimsel ve metinlerarası nitelikli metin, metinsel-aşkınlık araştırmalarının temel noktasını teşkil eder. Metinsel-aşkın okumaya ya da çözümlemeye tabi tutulan kompleks metin, ana-metin olarak adlandırılmaktadır. Kimi anlatılarda muhtemel olarak bilinç dışının ana-metne taşıdığı birer iz olarak mevcut bulunan gönderimler, her bir metinde yer alış biçimlerine ve temsil ettikleri anlamsal çerçevelere göre tasnif edilebilmektedir. Söz konusu tasnif, metinselaşkınlık kuramının teknik çerçevesini ve bu kuramı temsil ederek inşa edilmiş poetik nitelikli metinlerin meydana geliş sistematiğini ortaya koymaktadır. Belirli bir ana-metinde bulunan başka ve öteki unsurlar, yalnızca birer edebî malzeme olmakla kalmayıp farklı sanat alanlarına ait ürünlerden, kimi zaman bilimsel ifadelerden, parodi edilmiş "ciddi”" anlatım biçimlerinden, gazete kupürlerinden, basmakalıplaşmış söz zinciri parçalarından meydana gelmektedir. Tersi biçimde, edebiyat dışındaki sanat alanlarına da edebi malzeme, estetiksel-aşkın bir bezeyici olarak nüfuz edebilmektedir. Okuma edimi sırasında okur tarafından fark edilen kimi açık kimi kapalı her türden gönderim, metinsel-aşkınlık ilişsileri terminolojisinde bir yöntem olarak karşılık bulmaktadır.

Belirli bir örneklem temelinde mevcut terminolojide ana hatlarıyla yer alan metinsel-aşkınlık biçimleriyle bu biçimlerin ortaya çıkmasını ve yorumlanmasını sağlayan yöntemlere yer verilen bu incelemede, mevcut terminolojiye bir katkı olarak tespit edilen örnekler çerçevesinde özgöndergeleştirim, öz-alıntı, iç-alıntı gibi kavramlara başvurulmakta; söz konusu kavramlar, metinsel-aşkınlık ilişkileri kuramına dayalı incelemelerde göz önünde bulundurulmak üzere dikkatlere sunulmaktadır.

\section{Alıntı, Gönderge ve Gönderge-metin}

Bir ana-metinde belirgin biçimde tespit edilebilen metinsel-aşkınlık ilişkile- 
rini meydana getiren alıntılama ve göndergeleştirme, doğrudan doğruya belirli bir eser etrafında gerçekleşebileceği gibi, belirli bir konu, imge veya izleğin ana-metne yerleştirilmesi ya da belirli bir sanatçı ve üslubun ana-metinde anılması yoluyla da gerçekleşebilmektedir. Genellikle gönderge-metnin yazarının anılmasıyla ya da gönderge-metnin muhtevasından bahsedilmesi yoluyla gerçekleşen alıntı veya göndergemetin olarak yer verme biçimindeki bir göndergeleştirim işleminde okurun ekinsel birikimi ile okur hafızasından çok, yazara ait okuma geçmişinin etkisi bulunmaktadır. Anıştırma biçiminde gerçekleşen bir göndergeleştirimde ise metinsel-aşkınlık ilişkisi, büyük ölçüde okurun okuma tecrübesine bağlı olarak ortaya çıkarılmaktadır.

\subsection{Alıntı}

Alıntı, bir ana-metinde, kaynak belirtilerek, gönderge-metinden alınan kesitler yoluyla gerçekleştirilen metinsel-aşkın nitelikli göndergeleştirim işlemidir. Alıntıda, ana-metin içerisinde gönderge olarak bulunan metinler açıkça belirtilmektedir.

Ele alınan metinler arasinda bulunan Orhan Pamuk romanı Yeni Hayat'ta, 19. yüzyıl Fransız edebiyatı sahasında bilim kurgu ve fantastik konulu romanların yazarı Jules Verne ve romanı İsimsiz Aile, anlatı kişilerinin çocukluk ve gençlik yıllarında okumuş olduğu eserlerin yazarı olarak anılır. Roman, ana-metne bir gönderge hâlinde doğrudan alıntı yoluyla yerleştirilerek gönderge-metin olur: “'Ama bu yörede hiç ev yoktu, ylkıntılardan başka bir şey görülmüyordu. Bu harabeler zamandan değil de birtakım felaketler yüzünden oluşmus gibi görünüyordu.' Jules Verne, İsimsiz Aile" (Pamuk 2014b: 216). İsimsiz Aile'yi gönderge-metne dönüştüren aynı ibare, romanda bir iç-alıntı olarak yinelenir (Pamuk 2014b: 232). Böylece, Yeni Hayat bir özgönderge-metin olarak kendi içerisinde alıntılanmış olur.

\subsection{Gönderge}

Gönderge ise, gönderge-metinden doğrudan doğruya alıntı gerçekleştirilmeden, metnin gönderge olarak adının anılmasıyla, ya da gönderge-metnin yazarından bahsedilmesiyle (göndergeleştirim) gerçekleştirilen bir tür metinsel-aşkın gönderim sonucu ortaya çıkmaktadır. Gönderge-metin, bulunduğu ana-metinde alıntısız biçimde ortaya çıkan bir metinsel-aşkın unsurdur.

Yeni Hayat romanında, Andre Maurois'ye ait İklimler roman1, herhangi bir alıntılama işlemi gerçekleştirilmeden ana-metin içerisinde gönderge-metin olarak yer alır. Anlatıcı-kişi Osman'ın misafir olduğu bir evde, ev sahipleri arasında “And- 
re Maurois 'in 'İklimler' romanı hakkında” (Pamuk 2014b: 166) tartışılır. Bu sayede roman, gönderge-metinlerden biri olur. Böylece, 1970'li ve 1980'li y1llarda oldukça popüler olduğu anlaşılan İklimler romanı, ana-metni oluşturan metinsel-aşkın nitelikli kuruluş içerisinde göndergesel bir anlama sahip olur.

\subsection{Anıştırma ve Gizli Alıntı}

Anıştırma, bir ana-metinde doğrudan anılmaksızın, bir göndergeye, belirli bir esere, ifadeye ya da düşünceye sezdirme yoluyla gönderimde bulunulması biçimindedir. Anametinde meydana getirilen alıntı, anıştırma yöntemi söz konusu olduğunda, dolaylı ya da kapalı bir biçimde gerçekleştirilmektedir. Metinsel-aşkınlık ilişkilerini meydana getiren yöntemler arasında anıştırma, alımlayıcının/okurun okuma edimi sırasında da ortaya çıkarılan göndergeleştirim biçimlerinin başında gelmektedir. Nitekim, doğrudan doğruya belirli bir "yapı"ya gönderimde bulunulmayan bu türden bir "anımsama", metnin yazarından ya da eserin sahibinden bağımsız, özgül ve ekinsel tecrübeye bağlı olarak okuma edimi sırasında gerçekleşebilmektedir. Aktulum'un da “doğrudan belirtmeden sezdirim yoluyla gönderme yapılması" olarak (Aktulum 2011: 419) izah ettiği “anıştırma”"nın metinselaşkın düzlemdeki konumu, her bir okuma edimi sırasında yeniden belirlenebilmekte; bu sayede, farklı biçimlerde metinlerarası anlam üretilebilmektedir.

Orhan Pamuk romanlarından Beyaz Kale ${ }^{17}$, Miguel de Cervantes'e ait Don Quijote $^{18}$ romanının bir tür yenidenyazım biçimidir. Ana-metin Beyaz Kale 'de, alt-metin Don Quijote ile metinsel-aşkınlık bağlamında türeve dayalı bir öykünme ilişkisi, anıştırma tekniği sayesinde sağlanır. Alt-metin Don Quijote'un yazarı Cervantes'in, İnebahtı Savaşı sırasında Türklere esir düştüğü ve bir kolunu kaybettiği bilinmektedir. Bu durumun üstkurmaca bağlamda Don Quijote romanına da yansıdığı tespit edilebilmektedir. Ana-metin Beyaz Kale'de Venedikli adıyla anılan karakterin kürek mahkûmu olmaktan kurtulmak amaciyla hekim olduğunu söylemesi, Beyaz Kale için bir diğer alt-metin $\mathrm{Ka}$ nuni Devrinde Ístanbul ${ }^{19}$ ile ortak bir unsur olmakla beraber, iki alt-metni metinlerarası kılar. Ana-metinde ise Venedikli esirin cerrah olmadığını söyleme gerekçesi bakımından iki eser ayrışır. Beyaz Kale'de Venedikli, "gösterdikleri kolu kopmuş birini görünce cerrah olmadı̆̆ını söyle[r]” (Pamuk 2016a: 13). Burada anıştırılan kolu kopmuş kişinin Don Quijote'nin üstkurmaca anlatıcılarından biri ve kurmaca metnin yazarı Cervantes

17 Pamuk, Orhan (2016a), Beyaz Kale, İstanbul: Yapı Kredi Yayınları.

18 Cervantes Saavedra, M. d. (2017), La Manchalı Yaratıcı Asilzade: Don Quijote (Çev.: Roza Hakmen), 2 Cilt, 22. b., İstanbul: Yapı Kredi Yayınları.

19 Carım, Fuad (Haz.:) (1964), "Kanuni Devrinde İstanbul Dört asır yayımlanmadan köşede kalmış çok önemli bir eser", İstanbul: Yeni Savaş Matbaası. 
olduğu anlaşılmaktadır. Anıştırmanın sebebi ise ilk modern roman sayılan, postmodern edebiyat eserlerinin bilhassa yorumsal üst-metin ilişkisi ve üstkurmaca niteliklerinin arketipi niteliğindeki Don Quijote ile onun yazarı Cervantes'e yönelik öykünme (pastiş) ilişkisi olmalıdır. Beyaz Kale'de alt-metnin yazarı Cervantes ve Don Quijote ile öykünme yönlü metinsel-aşkın türev ilişkisi, romanın sonunda Hoca'nın İspanya'da kitaplar yazarak zengin olduğundan söz edilerek (Pamuk 2016a: 137) alt-metin Don Quijote'a yönelik diğer bir anıştırma ile eş-ruh teması üzerinden yeniden sağlanmaktadır.

Yeni Hayat romanında, Dr. Narin adıyla anılan karakterin Tanpınar'ı anımsatan bir ifadesinde, "Saat tıkırtısı bizim için tıpk cami avlusundaki şadırvanın şıkırtısı gibi, dünyayl fark etmenin değil, iç âleme geçmenin sesidir," (Pamuk 2014b: 135) ibaresiyle Ahmet Hamdi Tanpınar'a ait Bursa'da Zamann ${ }^{20}$ şiirinden bir parça kaynak gösterilmeden kısmen alıntılanarak anıştırılır. Ana-metinde Dr. Narin'in varlığı ve Tanpınar'ın tesiri, okurun dikkatine bırakılmıştır. Söz konusu alıntının "gizli” biçimde gerçekleştirilmesinin dikkatli okura yönelik bir "oyun” çağrısı olarak değerlendirilmesi olanaklı görünmektedir.

Orhan Pamuk romanlarında tespit edilen bir diğer gönderge-metin Oblomov $^{21}$, Pamuk romanlarında sıklıkla kendilik ve Doğu-Batı izlekleriyle bütünlük teşkil eden eş-ruh (Doppelgänger) ya da "ikizler"22 hikâyesinin kahramanları Hoca ile Venediklinin yaşam karşısında kayıısız kalmaya başlamalarıyla, Beyaz Kale'de eş-ruh imgesini oluşturan kutupların (Venedikli-Hoca) bir tür "Oblomovluk" sergilediklerinden söz edilen bölümde anıştırılmaktadır:

“Arada bir, Gebze'ye gidip kırık dökük değirmenleri ve herkesten önce bizi toraman çoban köpeklerinin karşıladığı köyleri gezerek gelirlerini denetliyor, kayıtları karıştırarak Kâhya'nın bizi ne kadar aldattığını anlamaya çalışıyor, kimi zaman gülüşerek, çoğu zaman da sıkıntıyla iç çekerek Padişah için eğlenceli risaleler yazıyor, başka bir şey de yapmiyorduk." (Pamuk 2016a: 95)

Hoca ile Venedikli'nin Gebze'de "Kâhya'nın kendilerini ne kadar aldattı̆ı̆nı anlamaya çallş̧maları]", Oblomov'un çiftliği ile ilgilenen kâhya tarafindan her yıl dolandırılmasını hatıra getirmektedir.

20 "Bursa'da bir eski cami avlusu,

Küçük şadırvanda şakırdıyan su;

Orhan zamanından kalma bir duvar..." "Bursa'da Zaman", (Tanpınar 2012: 50).

21 Gonçarov, İvan (2012), Oblomov (Çev.: Sabahattin Eyüboğlu-Erol Güney), 11. b., İstanbul: İş Bankası Kültür Yayınları.

22 Orhan Pamuk, "Kitaplarım Benim Hayatım" başlıklı değerlendirmesinde Beyaz Kale romanının temelinde ikizler hikâyesinin yattığını ifade eder (Pamuk 2016c: 34).

Jale Parla tarafından "ikizlik", bir tür başkalaşım izleği olarak ele alınmaktadır (Parla 2018: 252). Nitekim Beyaz Kale romanının örüntüsü de Hoca-Venedikli eş-ruh terkibi içerisinde bir tür başkalaşım, birbirine dönüşme izleği etrafında şekillenmektedir. 
Gizli alıntı ise, metinsel-aşkın tekniklerden biri olmakla beraber alıntıdan farklı olarak, gönderge-metinden ya da gönderge-metnin üreticisinden söz edilmeksizin, alıntı yapıldığı bildirilmeden metnin belirli bir bölümünün alıntılanarak ana-metne yerleştirilmesi biçiminde gerçekleşir. Anıştırma ile yakınlığı bulunmakla beraber, gizli alıntı, herhangi bir göndergeleştirme işleminin gerçekleştirilmediği montajlama biçimi olarak anlaşılabilir.

Orhan Pamuk romanlarından Sessiz Ev'de, 16. yüzyıl Azerbaycan sahası Türk edebiyatı temsilcisi Fuzûlî’ye ait Leylâ vü Mecnûn mesnevisinin Mecnûn'a atfedilen gazelleri içerisinden 2604 numaralı beyit ${ }^{23}$, kaynak gösterilmeksizin bir "gizli alıntı" biçiminde ana-metne girmiştir:

“[...] Okuduktan sonra kendisininmiş gibi gırtlağını şişirerek horoz gibi kasıldı şişko ve sonra bir daha:

\section{Öyle sermestem ki idrak etmezem dünya nedir}

\section{Men kimem saki olan kimdir mey-i sahba nedir}

diye okudu ve bu da kimin bilmiyorum dedi, Evliya'nın Seyahatname'sinden ve Ceylan ağzı açık Osmanlı alkol fiçısına gülümseyerek bakıyor ve daha da dinlemeye hazırlanıyordu [...]" (Pamuk 2015b: 183)

Fuzûlî’ye ait bir beyitin ana-metinde gizli biçimde alıntılanması, metinsel-aşkınlık ilişkileri bağlamında bir tür "aşırma"dan çok, "metinlerarası okur”a yönelik bir “oyun”un söz konusu olduğu düşüncesini ortaya çıkarmaktadır.

Ana-metnin üreticisinin ana-metin ya da bu metin dışında kendisine ait başka eserleri içerisinden gerçekleştirildiği takdirde, gizli alıntıdan, terminolojiye dâhil edilmek üzere bir örneklemi oluşturulmaya çalışılan “öz-alıntı” adıyla söz edilebilir. Nitekim Orhan Pamuk romanlarında gizli biçimde alıntılanmış ibarelerin genel olarak yazarın kendisine ait sözceler içerisinden gerçekleştirildiği ve yazar tarafindan üretilmiş metinlerin birer gönderge-metin (ya da özgönderge-metin) olarak anımsatıldı̆̆ı tespit edilebilmektedir.

\subsection{Gönderge-metin}

Metinsel-aşkın nitelikli bir ana-metinde yer alan gönderge-metin ise, ana-metin kabul edilen belirli bir metinde, herhangi bir alıntı gerçekleştirilmeksizin doğrudan doğruya anılmak suretiyle, bir kesitinin alıntılanarak bu kesitine ana-metinde yer verilmesiyle ya da anıştırma biçiminde bir tür geriçağırım yoluyla yer alan metinleri

23 "Öyle ser-mestem ki idrak etmezem dünyâ nedir

Ben kimim sâkî olan kimdir mey ü sahbâ nedir” (Fuzuli 2005: 379) 
Gizem KUNDURACI, Muharrem DAYANÇ, Orhan Pamuk Romanları Temelinde Metinsel-Aşkınlık

kapsamaktadır. Metinsel-aşkınlık ilişkilerinde belirli bir ana-metinde gönderge-metin durumunda yer alan metnin, metinlerarası anlam yönüyle etkili bulunması söz konusu metinsel-aşkınlık ilişkisinin niteliği bakımından bir ölçüt olarak kabul edilebilir. Nitekim, yalnızca oyunsu bir geriçağırma unsuru olarak ana-metinde yer aldığı varsayılan bir gönderge-metin, ana-metinle izleksel bakımdan bir bütünlük göstermediğinde yalnızca bir bezeme unsuru olarak dikkat çeker görünmektedir.

Gönderge-metinden ana-metne alıntılanarak giren kesit, alıntı yoluyla ana-metnin gövdesinde bulunmakla birlikte, epigraf ${ }^{24}$ biçiminde, genellikle bulunduğu bölümün anlamı hakkında bir tür ön-bilgi veren ya da ilgili bölümü özetleyen alıntılar olarak da yer alabilmektedir. Bir başka göndergeleştirim yöntemi olarak değerlendirilebilecek içanlat ${ }^{25}$ da epigraf gibi, belirli bir metnin indirgeme ${ }^{26}$ yoluyla ana-metne yerleştirilmesi biçiminde ortaya çıkan metinsel-aşkınlık biçimlerinden biridir.

Orhan Pamuk'a ait Kırmızı Saçlı Kadın romanında anlatının başkarakteri Cem Çelik, yaşamı boyunca okuduğu aktarılan baba ve oğul konulu metinlerden biri olan Şehnâme'den hareketle, sahip olduğu şirketin adını Sührab olarak belirler. Ana-metinde evladı bulunmayan başkarakterin genişlemekte olan şirketine verdiği isim, göndergemetnin ana-metinde izlekleştirilmesine zemin hazırlar. Ana-metinde yer yer bir ede-

\footnotetext{
24 Epigraf ya da "tanımlık" (Aktulum 2011: 474), biçim bakımından oldukça küçük bir hacme sahiptir ve diğer türlerdeki gönderge-metinlerden farklı olarak, metnin içerisinde değil, başında bulunur. Genellikle ana-metnin başında ve ana-metne ait bölüm başlangıçlarında yer verilen epigraf, ana-metni özetleyen veya ana-metnin içeriğini tamamlayan alıntılar biçiminde ortaya çıkar. Ana-metin ile yan-metinsellik ilişkisinde bulunan epigraflar, çoğunlukla farklı gönderge-metinlerden alınarak kolaj biçiminde yerleştirilen "alıntı" metinlerden oluşmaktadır. (Bk.: Kunduracı 2019: 99-101.)

25 Anlatı içinde anlatı olarak da adlandırılan içanlatı kavramını karşılamak üzere Gülsoy (2014: 18) tarafından ilk defa André Gide tarafından kullanılmaya başladığı belirtilen "sonsuzluğa düşüş" anlamındaki "la mise en abyme" ibaresi, resim içinde resim ya da metin içinde metin bulundurmayı sonsuz bir ayna imgesini anımsatacak biçimde kullanılmaktadır.

Orta çağ edebî anlatıları arasında yer alan diyalojik (söyleşimsel) yapısıyla metinsel-aşkın nitelikli metinlerle akrabalığı bulunan satirik "Menippea yergisi" türünden itibaren tespit edilmekte olan "türlerin bir aradalığı" ya da "melezleşme" olgusu, postmodernist metinlerde içanlatı olarak sürdürülmektedir. Bir anlatının içerisine yerleștirilen ikinci derecedeki bu "yeni" anlatı, kendisini kapsayan içeriğin izleksel bir tamamlayıcısı durumundadır. Aktulum, "anlatı içinde anlatı", "öykü içinde öykü", "içanlatı", "içöykü" ibareleriyle sözünü ettiği, "eylemlerine ya da izleklerine az çok bağlı kalarak ana metin içerisinde bir başka anlatıya yer verilmesi " biçiminde tanımladığı içanlatıdan, ilk olarak André Gide tarafından 1893 ’te bir "Journal" yazısında resim yahut sahneye yerleştirilecek dışbükey ve bulanık bir aynanın, sahnenin veya resmin içini yansıttı̆̆ düşüncesiyle bahsedildiğini belirtir (2011: 439). Ana-metni meydana getiren eserin konusunu yineleyen içanlatının, içerisinde yer aldığı ana-metnin taşıdığı anlama daha fazla açıklık getirdiği kabul edilmektedir. İçanlatının resim sanatı içerisindeki bir temsili olarak sanat tarihçilerince, "resim sanatının kendini fark etmesi” olarak açıklandığı belirtilen, ressam Velázquez'e ait "metakurmaca" Las Meninas (1656) "Nedimeler" adlı resimden yola çıkan Gülsoy, bir Hollanda kakao markası olan Droste kutularında bulunan iç içe geçmiş resimlerden hareketle, "Droste etkisi" olarak belirlenen yönteme değinir (2014: 26). Bir ana-metin ve bir iç-metin olmak üzere iki metnin çoğunlukla anlam veya izlek bakımından birbirleriyle "söyleşim" hâlinde bulunmasıyla, içanlatı, metinsel-aşkınlık ilişkilerini meydana getiren bir unsur durumuna gelmektedir. İçanlatılar, çoğunlukla "özet" ve "indirgeme” biçimindeki dönüştürüm yöntemleriyle, ana-metne uygun bir alt-metinden türetilen metinlerden oluşmakta; "ilk" ve "temel" metnin hikâyesini yinelemektedir.

26 Ana-metinde biçemsel bakımdan önemli ölçüdeki bir değişikliğin gerçekleştiği dönüştürüm yöntemlerinden biri olan indirgeme yöntemi, ana-metne aktarılan bir metnin, aktarım işlemi sırasında ve yenidenyazım sonucunda kısaltılarak dönüştürülmesi olarak anlaşılmaktadır. Belirli bir ana-metinde bulunan hikâye parçaları olarak açıklanması mümkün olan içanlatılar, büyük ölçüde özetlenmiş farklı metinlere dayandıklarından indirgeme tekniğinin en geniş ölçüde izlenmesi mümkün olan anlatı parçalarını oluşturmaktadır.
} 
biyat mahsulü olarak da anılmakta olan ve bu adla göndergeleştirilen İranlı mesnevi şairi Firdevsi'nin Şehnâme'sinde yer alan Rüstem ile Sührab'ın hikâyesi, ana-metinle izleksel bakımdan bir birliktelik sergilemektedir. Şehnâme mesnevisindeki hikâyede yer alan Rüstem ve Suhrâb adlı başkarakterler, ana-metin Kırmızı Saçlı Kadın'ın çatı hikâyesinin başkarakterleri Akın Çelik ve Cem Çelik'in baba-oğul izleği etrafındaki kurgusal hikâyelerini aktarmada izleksel bir yardımcı/dayanak konumundadırlar. $\mathrm{Bu}$ sayede gönderge-metin, ana-metnin izleksel çerçevesini oluşturmada metinsel-aşkınlık ilişkilerine başvurulması hususunda bir geriçağırım işlemi neticesinde anımsanan göndergeyi temsil etmiş olmaktadır. Bu sayede akraba karakterlerin tasarlanması yoluyla evrensel edebiyat tasavvuruna yönelik Doğu-Batı ekseninde ikiz veya farklı göndergemetinlerin de anımsanmasıyla daha fazla katmanlı eş-izleksel kurgusal hikâyeler meydana getirilmiş olmaktadır.

\section{Metinsel-Aşkınlık Terminolojisinde Değerlendirilmek Üzere Tespit Edilen Yöntemler ve Adlandırmalar}

Metinsel-aşkınlık terminolojisinde yer almakta olan ve metinsel-aşkınlık temelindeki okumalarda birer yöntem olarak tespit edilebilen anıştırma, alıntı, gönderge gibi teknik unsurların yanı sıra, öz-alıntılama, iç-alıntılama, öz-göndergeleştirim gibi birtakım metin ötesi ve metin içi kurgulama yöntemleri, ele alınan metinler içerisinden tespit edilmektedir. Bulundukları bağlama göre ana-metinlerde birbirinden farklı anımsama ve gönderimler neticesinde ürettikleri anlam, söz konusu montajlama biçimlerini birer yöntem olarak ele almayı mümkün kılmaktadır. Bunlardan iç-alıntı yöntemi ve sayesinde mümkün olan öz-göndergeleştirim, alıntı ve göndergenin bulunduğu metnin kendisine bir referans sağlamasını sağlamaktadır. Öz-alıntı yöntemi sayesinde gerçekleşen öz-göndergeleştirim yoluyla ise, ana-metinde anımsanan ve söz konusu metinle arasında metin ötesi bir ilgi kurulan aynı yazara ait başka metinler, tek tek yapıtlardan meydana gelen daha büyük bir ana-anlatı, başka bir ifadeyle bir nehir roman tasavvurunu ortaya koyar görünmektedir.

\section{1. Öz-alıntı ve İç-alıntı Yöntemleri}

Orhan Pamuk romanlarından hareketle metinsel-aşkınlık ilişkileri kapsamında tespit edilmiş ve öz-alıntı ile iç-alıntı olarak adlandırılmış olan yöntemler, genellikle oyunsu bir üslup özelliği gibi görünmekle birlikte ana-metinde izleksel bakımdan bir tür vurguyu sağlama işlevine sahiptir. 
Öz-alınt1, bir ana-metnin yazarının ya da üreticisinin kendi eserleri arasından bir kesite, görüşe yahut ibareye, alıntı, gönderge veya gizli alıntı biçiminde ana-metinde yer vermesi biçiminde gerçekleşen alıntılama biçimi olarak metinsel-aşkın bir tekniktir. Ana-metnin üreticisinin, kendisine ait, ana-metinde bulunmayan ancak kendisine ait olduğu tespit edilebilen, çoğunlukla aynı metin üreticisinin farklı eserlerinden ana-metne yerleştirilen alıntılar, öz-alıntı olarak kabul edilmektedir. Kendi eserinden öz alıntılama işlemini gerçekleştiren yazar, ana-metinde, ana-metin dışında kalan eserlerine göndergemetinler (özgönderge-metin) olarak gönderimde bulunmaktadır. Orhan Pamuk romanlarında, ana-metne "gizli" biçimde, kaynak gösterilmeksizin yerleştirildiği tespit edilen alıntılar, çoğunlukla romanın yazarına ait metinlerden birer öz-alıntı olarak gerçekleştirildiğinden, söz konusu alıntı ve göndergeler bu başlık altında değerlendirilmiştir.

İç-alıntı, öz-alıntı ile birlikte, metinsel-aşkınlık ilişkilerini meydana getirdiği tespit edilen yöntem adlandırmalarına öneri olarak tercih edilmiş kavramlardan bir diğeridir. Bir ana-metnin içerdiği düşüncenin, ifadenin ya da belirli ibarelerin söz konusu ana-metinde yinelendiği durumlarda gerçekleştirildiği tespit edilen "alıntı" işleminden "iç-alıntı" olarak söz edilebilir. İç-alıntılama işlemi, alıntı ve göndergeleştirme yoluyla gerçekleştirilebileceği gibi, gizli alıntı biçiminde de meydana getirilebilmektedir. İç-alıntı, ana-metin içerisinde söz konusu ana-metinden gerçekleştirilen alıntı işlemiyle, başka bir ifadeyle bir tür "yineleme" yoluyla ortaya çıkmaktadır. Ana-metinde yinelenen her türlü unsur birer iç-alıntı olmakla beraber, belirli bir metinde tekraren yer verilen ibarelerden meydana gelen "leitmotif" kullanımı da bir tür iç-alıntı olarak kabul edilebilmektedir. Bir ana-metinde tespit edilen iç-alıntılama yöntemi, herhangi bir gönderge-metin ya da epigraf içeriğinin yinelenmesi yoluyla gerçekleştirilebilmektedir. Bunun yanında, ana-metnin kendisine ait bir bölümün yinelenmesi durumunda yöntemin asıl işlevi meydana getirilmektedir.

Orhan Pamuk'a ait roman Masumiyet Müzesi'nde de birkaç defa uygulanan iç alıntılama tekniği ile alıntılanan metin yinelenmiş, böylece ana-metin, özgöndergemetin durumuna getirilmiştir:

"Ertesi günkü buluşmamızda, Füsun bana küpesinin tekinin kayıp olduğunu söyledi. Aslında, o gittikten sonra ucunda adının baş harfi olan küpeyi mavi çarşafların arasında görmüş, kenara kaldıracağıma, tuhaf bir iç güdüyle, kaybolmasın diye ceketimin cebine koymuştum. 'Burada canım,' dedim. Sandalyenin arkalığına asılı ceketimin sağ cebine elimi attım. 'Aaa, yok,' dedim. Bir an bir felaketin, bir uğursuzluğun belirtisini hisseder gibi oldum, ama sabah sicağ fark edince, başka bir ceket giydiğimi hemen hatırladım. 'öteki ceketimin cebinde kalmış.' 
'Lütfen yarın getir, unutma,' dedi Füsun gözlerini kocaman açarak. 'Benim için çok önemi var.'

'Peki."' (Pamuk 2008: 12)

Ana-metnin başlangıç sayfalarında yer alan kısım, “Artık Bütün Hayatım Seninkine Bağlı" başlıklı on yedinci bölümde yinelenir:

“'Dün taktığım küpenin teki kayıp,' dedi beni öptükten sonra. 'Burada canım,' dedim. Sandalyenin arkalığına asılı ceketimin sağ cebine elimi attım. 'Aaa, yok,' dedim. Bir an bir felaketin, bir uğursuzluğun belirtisini hisseder gibi oldum, ama sabah sıcağı fark edince, başka bir ceket giydiğimi hemen hatırladım. 'Öteki ceketimin cebinde kalmış.'

'Lütfen yarın getir, unutma,' dedi Füsun gözlerini kocaman açarak. 'Benim için çok önemli.'” (Pamuk 2008: 86)

Füsun’un kayıp küpesinin romanın örüntüsü bakımından öneme sahip olduğu, ana hikâyenin bu eşyaya dair muhtevasından anlaşılmaktadır. Nitekim başkarakter Kemal Basmacı, küpelerin kayıp tekini ailesiyle beraber yaşadığı evde de aramaya devam eder, evlerinde görevli bulunan Fatma Hanım'a bir küpe teki görüp görmediğini sorar. Küpeyi Fatma Hanım da görmemiştir. Kemal ile Sibel'in nişanlandıkları ve Kemal'in 1stırabı ile müzenin hikâyesinin başlamak üzere olduğu gece, Füsun'un 'Sevdiklerimizi kaybedince, onların adlarını ruh çağırma oyunlarında taciz etmeyelim... Onun yerine, onları hatırlatacak bir eşya, ne bileyim, mesela bir küpe bile, bizi yıllarca çok daha iyi teselli edebilir." (Pamuk 2008: 161) ifadeleri, söz konusu küpelerin romanın ve Masumiyet Müzesi adlı mekânın kuruluşundaki tesire dikkat çeker görünmektedir.

Masumiyet Müzesi, mimetik özellikli bir müze-eserdir. Müzenin, ansiklopediroman Masumiyet Müzesi’ni meydana getiren hikâyenin mekâna dönüşmesini temsil ettiği görüşünden hareketle, Füsun'un küpelerinin Kemal ile Füsun arasındaki duygusal yakınlığın bir temsili olarak tasavvur edildiği anlaşılmaktadır. Nitekim, Müze’nin bu mekânında " 1 ” numaralı kutuda bulunan ve ilk sergilenen eşya Füsun'un küpesi olmuş; romanda da önce küpenin hikâyesi anlatılmıştır. Böylece, romanda ve müzede simgesel aktarımı sağlayan küpenin kaybolduğunu anlatır bölüm bir iç-alıntıya dönüştürülüp yinelenmekte; küpeler simgeleştirilmektedir.

\section{2. Özgönderge-metin}

Kırmızı Saçlı Kadın romanında Rüstem ile Sührab olarak ele alınmış olan Şehnâme'de bulunan gönderge-metin, Pamuk'a ait diğer bir ana-metin Benim Adım 
Kırmızı'nın metinsel-aşkın nitelikli okumasıyla tespit edilebilmektedir. Ana-metinde çatı hikâyenin karakterleri olan nakkaşlar, mesnevi hikâyesindeki kimi meclisleri nakşetmektedirler. Ana anlatının anlatım kipinin veya düzleminin değiştirilmesi yoluyla minyatür görünümleri betimlenen mesnevi meclisleri, ekfrastik birer sahneye dönüştürülerek alt-metin sayılan mesnevi hikâyesinin ana-metinde yenidenyazım yoluyla işlenmesini sağlamaktadırlar. Böylece, ana-metin Kırmızı Saçlı Kadın'ın izleksel çerçevesinin tespitinde dikkate alınan Pamuk'a ait öncül nitelikli diğer bir roman olan Benim Adım Kırmızı, ana-metnin yazarına ait bir başka kurmaca metin olarak özgönderge-metin kabul edilmektedir.

Terminolojide yer alan gönderge-metin kavramının yanında özgönderge-metin biçimindeki farklı bir adlandırmaya başvurulmasının sebebi, ana-metinlerde göndergeleştirilen ana-metnin yazarına ait "başka" "öteki” gönderge-metinlerin varlığ 1 ile bu özerk ve müstakil metinlerin toplamından oluşan büyük bir anlatının meydana getirildiğinin tespitine dayanmaktadır. Metinsel-aşkın düzlemde diğerlerinden bağımsız hâlde bulunan ve ayrı birer bağlam teşkil eden her bir "metin", kendi özgül "anlam"ina sahip olmakla birlikte, özgöndergeleştirim işlemi sayesinde bir araya getirildiklerinde bir tür nehir romanın birbiriyle ilintili anlatı parçaları olarak değerlendirilebilmektedir. Özalıntılar yoluyla ana-metinlere yerleştirilen yazara ait gönderge-metinler (özgöndergemetin), bulundukları ana-metin içerisinde kurgusal ve anlatımsal bir tutarlılı̆ın yanı sıra metinsel-aşkınlık bağlamında anlamsal ve izleksel bir bütünü oluşturmaktadır.

Orhan Pamuk romanlarından Sessiz Ev'in karakterleri arasında bulunan Fatma Hanım, anlatı boyunca, gençlik yıllarında Şükrü Paşa'nın kızlarıyla arkadaşlık ettiğini anımsar. Şükrü Paşa'nın kızları, Pamuk'a ait bir diğer roman Cevdet Bey ve Oğulları'nın da kişilerini oluşturmakla birlikte, kız kardeşlerden Nigân Hanım, hikâyenin etrafında teşekkül ettiği Cevdet Bey'in hanımıdır. Gönderge-metin Cevdet Bey ve Oğulları, Sessiz Ev'de bir ölüm ilânı münasebetiyle alıntı yoluyla ana-metne yerleştirilir:

"Vefat: Evkaf Nazırı ve Paris sefiri merhum Şükrü Paşa'nın kızı ve merhume Türkân ile Şükran'ın kız kardeşleri, Nigân Işıcçı Hanımefendi, aah Nigân abla, senin de hakkın rahmetine kavuştuğunu okur, böylece elimde ölüm ilanları soğuk odanın ortasında öyle dururken ben İstanbul'da tanıdık kimsenin kalmadığını anlarım [...]" (Pamuk 2015b: 298)

Şükrü Paşa'nın kızları, ana-metin Cevdet Bey ve Oğulları ile ana-metin Sessiz Ev'de bir gönderge-metin olarak bulunan Robinson Crusoe okumalarıla söz konu- 
su gönderge-metnin metne girmesini sağlarlar. Nitekim, Cevdet Bey ve Oğulları'nda Nigân Hanım'ın oğlu Refik, gönderge-metni büyük ölçüde idealize etmekte ken; Sessiz Ev'de ise Fatma Hanım, kızların okudukları, babaları Şükrü Paşa'ya ait olduğu belirtilen kitap “Hikâye-yi Robenson”u ödünç aldığını anımsamaktadır. Avrupa edebiyatında kanonlaşmış bir eser olan gönderge-metin, her iki ana-metinde de Paris sefirliği görevini yürütmüş olan Şükrü Paşa münasebetiyle yer almaktadır.

Daha geniş bir ifadeyle, Cevdet Bey ve Ŏgullarl romanının karakterlerinden Masumiyet Müzesi romanında da söz edilmektedir: Kemal Basmacı'nın babası Mümtaz Bey'in vefatıyla, gazetelere vefat ilânı verildiğinde ilân metni için, Kemal'in annesi Vecihe Hanım, “Şükrü Paşa'nın kızları Nigân, Türkan ve Şükran'ın sırası da yanlış yazılmış...”, (Pamuk 2008: 252) der. Hatırlandığı gibi, Şükrü Paşa ve kızları, Cevdet Bey ve Oğulları'nın kişileridir. Nigân Hanım ise Cevdet Işıkçı'nın eşi olarak ana karakterler arasındadır. Yine bir ölüm ilânı içerisinde ana-metne yerleştirilen özalıntılanmış ibare, söz konusu üç romanı eş-kurgusal okunmasını mümkün kılmakta, farklı bir bakış açısıyla ise bu üç metnin birbiriyle metinlerarası okunmasını zorunlu kilmaktadir.

Beyaz Kale'de muhasara altına alınan Doppio Kalesi, Masumiyet Müzesi'nin kurmaca örüntüsüne bir takvim yaprağında bulunan "tarihte bugün” köşesiyle girer. Kemal Basmacı'nın hatıralarında “'3 Eylül 1658, bugün Osmanlı Ordusu'nun Doppio Kalesi kuşatması başladı, 'diye okurdu Füsun. Ya da '26 Ağustos 1071, bugün Malazgirt Meydan Muharebesi'nden sonra Türklere Anadolu'nun kapıları açıldı. ,' (Pamuk 2008: 365) biçiminde alıntılanarak öz-alıntıyı meydana getirmiş olur. Kurgusal karakterlerin her iki romanda farklı bağlamlarda yer alması, söz konusu iki ana-metni birbiriyle bağıntılı biçimde okumayı olanaklı ve gerekli kılar.

\section{Sonuç}

Metinsel-aşkınlık ilişkileri, orta çağ karnaval geleneğine bağlı biçimde gelişen karnavallaşmış romanlarda türlerin bir araya gelişi, bu sayede ortaya çıkan melez anlatılarda parodi, burlesk gibi anlatımsal dönüşüme dayalı türev ilişkilerinin meydana gelmesiyle ve ana-metinlerde palimpsest anlatıların izlerinin sürülmesiyle ortaya çıkmaktadır. Bu durum, söyleşim ve çokseslilik kavramlarıyla ifade edilebilmektedir. Çoksesli niteliğe sahip ve kendisi dışındaki her türlü “metin”le söyleşim hâlinde bulunabilen ana-metin, metinsel-aşkın niteliklidir. Metinsel-aşkın nitelikli bir metnin okunması ve çözümlenmesi ise bu bağlamlı bir yaklaşımla gerçekleşmektedir. Büyük ölçüde okura 
bağlı biçimde ortaya çıkan metinsel-aşkınlık ilişkileri bağlamlı anlam, aynı zamanda belirli metinlerde kuramsallaşmış bir kuruluş biçimini temsil etmektedir.

Metinsel-aşkınlık ilişkileri kuramı, Rus Biçimcilerinden bilhassa Mihail Bahtin'in çokseslilik (polyphony) ve söyleşim (dialogy) kavramları üzerinde şekillenirken, Julia Kristeva tarafindan bu kavramlardan hareketle metinlerarası (intertextuality) kavramı ortaya koyulmuştur. Gérard Genette ise metinlerarasılık kavramını metinselaşkınlık (tranxtextuality) ibaresiyle ifade etmiş ve bu türden ilişkiler üzerine bir tasnif ve terminoloji meydana getirmiştir. Genette'e göre metinlerarası (intertextuality), metinsel-aşkınlık biçimlerinin bir türünü oluşturmaktadır. Kurama ve söz konusu ilişkilerin ortaya çıkış biçimlerine dair Türkçe terminoloji, Aktulum tarafından sistemleştirilmiştir.

Metinsel-aşkınlık ilişkileri kuramı terminolojisinde alıntı ve gönderge kavramlarından hareketle teşekkül eden gönderge-metin kavramı bulunmaktadır. Bununla birlikte gönderge-metin, çoğunlukla ana-metinde çağrışımsal bir gönderim değerine sahip, metnin bütününün anlamını oluşturmada başvurulan ya da anımsanan bir izselleştirilmiş metin olarak yer almaktadır. Bu incelemede gönderge-metin kavramından yola çıkılarak tasarlanmış olan ancak işlev bakımından gönderge-metinden farklı özgönderge-metin (selfreferential-text) kavramı, tespit edilen gönderim işlemlerinde ana-metnin yazarına ait metin ya da ibarelerin ana-metin içerisine geriçağırım yoluyla yerleştirilerek çoğunlukla izleksel bir metinlerarası anlam meydana getiren kullanımlar için önerilmektedir.

Özgönderge-metin, ana-metnin yazarına ait "başka", "öteki” metinlerin ya da sözcelerin ana-metne yerleştirilmesi (öz-alıntı ve bunun sonucunda özgöndergeleştirim) yoluyla bir tür gönderge-metin olan bu tür alıntı ve anımsamalar, çoğunlukla ana-metni bir bütünün parçası kılmakta, her bir müstakil metin bir araya getirildiğinde bunlardan müteşekkil büyük bir ana-metin, başka bir ifadeyle bir nehir roman oluşturmaktadır. Aynı biçimde, iç-alıntı (internal-citation) yöntemiyle de söz konusu ana-metnin içerisinden belirli bir parça alınıp başka bir yerde yinelenerek söz konusu ana-metindeki bir izlek, imge veya ibare vurgulanmakmış olmaktadır.

Belirli bir ana-metin içerisinde özgönderge olarak tespit edilen her türden alıntı, metin üreticisinin kendisine ait sözceleri içermesi bakımından birer "öz" alıntılama biçimi olarak yorumlanmaktadır. Böylece, öz-alıntılama (metin üreticisinin ana-metin içerisinde bulunan bir sözcesini yinelemesi ya da kendine ait bir başka sözceden alıntılaması) ve bunun sonucunda özgöndergeleştirim (selfreferation) ediminden hareketle öz-alıntı (self-citation) yöntemi bir metinsel-aşkınlık tekniği olarak ortaya çıkmaktadır. 


\section{Kaynakça}

Aktulum, Kubilây (1999), Metinlerarası İlişkiler, Ankara: Öteki Yayınları.

Aktulum, Kubilây (2011), Metinlerarasılık/Göstergelerarasılık, Ankara: Kanguru Yayınları.

Bakhtin, M. Mikhail (1981), The Dialogic Imagination: Four Essays (Ed.: Michael Holquist; Trans.: Caryl Emerson-Michael Holquist), Texas: University of Texas Press, Austin.

Bahtin, M. Mihail (2014), Karnavaldan Romana: Edebiyat Teorisinden Dil Felsefesine Seçme Yazılar (Çev. Cem Soydemir, Der. Sibel Irzık), 2. b., İstanbul: Ayrıntı Yayınları.

Bahtin, M. Mihail (2005), Rabelais ve Dünyası (Çev. Çiçek Öztek), İstanbul: Ayrıntı Yayınları.

Bahtin, M. Mihail (2015), Dostoyevski Poetikasının Sorunları (Çev.: Cem Soydemir), 2. b., İstanbul: Metis Yayınları.

Barthes, Roland (1977), “The Death of Author”, Image, Music, Text (Ed.\&Trans.: Stephen Heath), London: Fontana Press.

Barthes, Roland (2016), Göstergebilimsel Serüven (Çev.: Mehmet Rifat - Sema Rifat), İstanbul: Yapı Kredi Yayınları.

Carım, F. (Haz.:) (1964), “Kanuni Devrinde İstanbul Dört asır yayımlanmadan köşede kalmış çok önemli bir eser”, İstanbul: Yeni Savaş Matbaası.

Cervantes Saavedra, Miguel d. (2017), La Manchalı Yaratıcı Asilzade: Don Quijote (Çev.: Roza Hakmen), 2 Cilt, 22. b., İstanbul: Yapı Kredi Yayınları.

Defoe, Daniel (1997), Robinson Crusoe (Çev.: Akşit Göktürk), İstanbul: Yapı Kredi Yayınları.

Firdevsi, Şehname I (Çev.: Necati Lugal, Kenan Akyüz), Milli Eğitim Bakanlığı Yayınları, İstanbul, 1945.

Firdevsi, Şehname II (Çev.: Necati Lugal), Milli Eğitim Bakanlığı Yayınları, İstanbul, 1994.

Firdevsî, Şehname IV (Çev.: Necati Lugal), Milli Eğitim Basımevi, İstanbul, 1994.

Fuzuli, Leylâ vü Mecnûn (Haz.: Hüseyin Ayan), 3. b., Dergâh Yayınları (1. Baskı: 1981), İstanbul, 2005.

Genette, Gérard (1997a), Palimpsests: Literature in the Second Degree (Trans.: Channa Newman, Claude Doubinsky), USA: University of Nebraska Press.

Genette, Gérard (1997b), Paratexts: Theresolds of Interpretation (Trans.: Jane E Lewin, Foreword.: Richard Macksey), USA: Cambridge University Press.

Gonçarov, İvan (2012), Oblomov (Çev.: Sabahattin Eyüboğlu-Erol Güney), 11. b., İstanbul: İş Bankası Kültür Yayınları.

Gülsoy, Murat (2014), 602. Gece: Kendini Fark Eden Hikâye, İstanbul: Can Yayınları. 
Gizem KUNDURACI, Muharrem DAYANÇ, Orhan Pamuk Romanları Temelinde Metinsel-Aşkınlık

Kristeva, Julia (1980), Desire in Language: A Semiotic Approach to Literature and Art (Ed.: Leon S. Roidiez; Trans.: Thomas Gora, Alice Jardine, Leon S. Roidiez), New York: Columbia University Press.

Kundurac1, Gizem (2019) "Metnin Ötesinde, Metinler Arasında Dolaşım: Orhan Pamuk'un Romanlarında Metinsel-Aşkınlık Görünümleri”, Eskişehir: Eskişehir Osmangazi Üniversitesi Sosyal Bilimler Enstitüsü: (Yayınlanmamış Doktora Tezi).

Maurois, Andre (1967), İklimler (Çev.: Tahsin Yücel), İstanbul: Varlık Yayınları.

Pamuk, Orhan (2008), Masumiyet Müzesi, İstanbul: İletişim Yayınları.

Pamuk, Orhan (2014a), Cevdet Bey ve Oğulları, İstanbul: Yapı Kredi Yayınları.

Pamuk, Orhan (2014b), Yeni Hayat, İstanbul: Yapı Kredi Yayınları.

Pamuk, Orhan (2015a), Benim Adım Kırmızı, İstanbul: Yapı Kredi Yayınları.

Pamuk, Orhan (2015b), Sessiz Ev, İstanbul: Yapı Kredi Yayınları.

Pamuk, Orhan (2016a), Beyaz Kale, İstanbul: Yapı Kredi Yayınları.

Pamuk, Orhan (2016b), Kırmızı Saçlı Kadın, İstanbul: Yapı Kredi Yayınları.

Pamuk, Orhan (2016c), Öteki Renkler, 3. b., İstanbul: Yap1 Kredi Yayınları.

Parla, Jale (2018), Türk Romanında Yazar ve Başkalaşım, 4.b., İstanbul: İletişim Yayınları.

Propp, Vladimir (2008), Masalın Biçimbilimi (Çev.: Mehmet Rifat, Sema Rifat), İstanbul: İş Bankası Kültür Yayınları.

Saussure, Ferdinand de (1998), Genel Dilbilim Dersleri (Çev.: Berke Vardar), İstanbul: Multilingual Yayınları.

Tanpınar, Ahmet Hamdi (2012), Bütün Şiirleri (Haz.: İnci Enginün), 12. b., İstanbul: Dergâh Yayınları.

Vardar, Berke vd. (2007), Açıklamalı Dilbilim Terimleri Sözlüğü, 2. b., İstanbul: Multilingual Yayınları.

Verne, Jules (1964), Ísimsiz Aile (Çev.: Ferid Namık Hansoy), İstanbul: İnkılap Yayınları.

Yücel, Tahsin (2008), Yapısalcılık (Haz.: Faruk Duman), İstanbul: Can Yayınları. 